\title{
Challenges of Implementing Foreign Manpower Policy During the Covid-19 Pandemic in Indonesia
}

\author{
Darmawan Yusuf ${ }^{1}{ }^{*}$ Ningrum Natasya Sirait ${ }^{2}$, Agusmidah $^{2}$
}

\author{
${ }^{1}$ Doctor Program Faculty of Law, Universitas Sumatera Utara, Medan \\ ${ }^{2}$ Lecturer Faculty of Law, Universitas Sumatera Utara, Medan \\ Email: darmawanyusuf2021@gmail.com
}

\begin{abstract}
Foreign Workers continue to arrive even during the Covid-19 Pandemic. The existence of regulations related to the control of foreign workers is Law No. 11 of 2020 concerning Omnibus Law is unable to stem the influx of foreign workers. This condition has given rise to pros and cons in society. This paper discusses the entry of foreign workers during the Covid-19 Pandemic into Indonesia, which undermines the meaning of social justice, because, in the midst of society surviving during the pandemic, the State also sided with the capitalists. The problem is how the policies of the Government of the Republic of Indonesia are reviewed from the Law No. 11 of 2020 concerning Omnibus Law in dealing with the entry of foreign workers during the pandemic. In addition, it turns out that the Omnibus Law has submitted a judicial review and a formal review to the Constitutional Court whether it violates the 1945 Constitution of the Republic of Indonesia or not. Normative legal research is descriptive. The results of the study show that the State, especially the Government of the Republic of Indonesia does not side with the job seekers to fulfill their needs. When the State is needed in the midst of society, there the State also harms the meaning of "social justice" as the spirit of the purpose of the state. The State should be more sensitive to the community by making policies that reflect the meaning of social justice.
\end{abstract}

Keywords: Foreign Workers, Pandemic, Justice, Social

\section{INTRODUCTION}

\subsection{Background}

The Government of the Republic of Indonesia has issued a policy of Enforcement of Community Activity Restrictions (PPKM) from September 21 to October 4, 2021 to anticipate the spread of the Covid-19 virus. However, when PPKM was strictly enforced, a number of Foreign Workers (TKA) were reported to have arrived in Indonesia. Precisely on May 8, 2021, a total of 157 foreign workers from China arrived in Indonesia using the China Southern Airlines CZ387 aircraft from Guangzhou. This condition is considered ironic by several groups, including the Confederation of Indonesian Workers Union (KSPI).[1] Still during the Covid-19 Pandemic, September 2020, the group of foreign workers also entered through Cut Nyak Dhien Airport.[2] In fact, in mid-2020, as many as 500 foreign workers were reported to have arrived in Konawe, Southeast Sulawesi.[3]
The arrival of foreign workers for a long time has caused rejection in the community. There is an assumption that the arrival of foreign workers is not needed, given the high unemployment rate in Indonesia, especially during the current Covid-19 pandemic.[4] The Indonesian government's action to allow the entry of the foreign worker group is considered counter-productive to the policies of several countries which have actually closed the door for foreign workers to reduce the impact of the pandemic, including for Indonesian Migrant Workers (TKI). The community's refusal is actually inversely proportional to the reaction from several related agencies, the Indonesian Ministry of Manpower stated that the presence of foreign workers is needed to provide expert support.[5]

Meanwhile, the Director-General of Immigration, Ministry of Law and Human Rights stated that the arrival of foreign workers was needed to assist the National Strategic Project.[6] Therefore, it is interesting to discuss about the policies of the Government of the Republic of 
Indonesia in dealing with the entry of foreign workers during the pandemic.

Based on the theory of justice presented by Aristotle, quoted by Bahder Johan Nasution, [7] Aristotle said that equality of rights is indeed a concept of justice. However, justice is not always about equal rights, but also about the unequal rights that people get. That is, justice will be achieved if some parties are treated the same or vice versa, some of these parties are not treated the same. In the context of this paper, the justice meant is commutative justice (together) which reflects social justice for all Indonesian people. For example, treating everyone fairly, not only getting their rights but also having to accept sanctions or punishments when they make mistakes.

Article 27 paragraph (2) of the 1945 Constitution of the Republic of Indonesia instructs the State to provide job security guarantees to every Indonesian citizen. Therefore, a decent job and living is a basic right for every Indonesian citizen. The basic right to work for every citizen is attached to Article 27 paragraph (2) of the 1945 Constitution, which states: "Every citizen has the right to work and a decent living for humanity". The provision of Article 27 paragraph (2) of the 1945 Constitution is a guarantee of social justice as enshrined in the Fifth Precept of Pancasila, which states that: "Social justice for all Indonesian people". Work and life are one coin with two different sides. Everyone works to live and lives to get a decent life.

\subsection{Problem}

Based on this background, the problems in this paper can be formulated as follows: What is the policy of the Government of the Republic of Indonesia in dealing with the entry of foreign workers during the pandemic?

The purpose of this paper is to get an overview of the policies of the Government of the Republic of Indonesia in the field of manpower in dealing with the entry of Foreign Workers (TKA) during the Covid-19 Pandemic.

\section{METHODS}

This paper uses a descriptive normative research method and a library approach. The data sources used are secondary data in the form of legal material sources, consisting of: legislation in the field of manpower, the policies of the Government of the Republic of Indonesia in the field of dealing with the Covid-19 pandemic, international and national journals, plus law and manpower dictionaries.

\section{RESEARCH RESULTS AND DISCUSSION}

\subsection{The State's Obligation to Protect Its Citizens}

The influence of law in regulating human life is well described by van Apeldoorn that humans are always controlled by law. The law interferes in human affairs before he is born, even after he dies. The law protects the seed conceived by a mother and protects the body of the dead. The law also gives a person's rights directly from his parents after he is born and places obligations directly from his parents after he is born and places obligations on parents towards their children. Apeldoorn also emphasized that since birth, humans are objects of rights. In this connection, an infinite number of legal ties between humans are supporters of rights, and all things that surround humans are objects of rights. In this connection, there are innumerable legal ties between humans and the physical world that surrounds them and that the association of human life that occurs from direct relationships from the origin, blood ties, marriage, residence, nationality, trade, provision of services various types (rental, transportation, storage, insurance money loans, etc.). All relationships are regulated by law and all are legal relationships (Rechts betrekkingen).[8]

In modern life, various advances in science and technology have marked the pattern of relationships between individuals in society. But as Aristotle said, humans are basically social creatures who always want to hang out and gather with each other, because they like to socialize (zoon politicon). Behind what has been achieved in the progress of human civilization which is supported by elements of science and technology, law plays an important role in maintaining social balance in society, harmonizing differences in interests that arise, regulating the allocation of limited resources, balancing, and directing human behavior. in interacting with the larger society. Without the law, humans will inevitably only prey on other humans who are weaker (homo homini lupus).

The essence of providing legal protection to Indonesian citizens is a protection against ensuring a sense of security from all forms of external threats, including the division of employment regulated by the Government. That is, to protect against arbitrary actions from people, groups, and the state to achieve justice and legal certainty. Legal protection means identifying that there are two related parties. Some people must be protected from arbitrary actions, some must provide protection.

The legal protection is also inherent in the concept of "rechtsstaat" and the concept of "the rule of law". However, it should still be realized that the Republic of Indonesia was built, which was proclaimed on August 17, 1945, standing on the basis of the ideology and 
philosophy of the State "Pancasila". Therefore, the concept of "State of Law" must be returned to Pancasila as its basis, and automatically legal protection for Indonesian citizens as job seekers must be based on Pancasila because recognition of human dignity is intrinsically attached to Pancasila itself.

\subsection{Regulation of Control of Foreign Workers (TKA)}

Indonesia's involvement in the World Trade Organization (WTO) and the ASEAN Free Trade Area (AFTA) has made Indonesia unable to avoid globalization, including the globalization of labor, which has made the traffic of trade in goods and services and the movement of people borderless.[9] Lawrence M. Friedman's view is correct, which says that the law is not autonomous, but on the contrary, the law is open at all times to outside influences.[10]

This condition makes Indonesia no longer able to prevent the entry of foreign workers into Indonesia, so what can be done now is to control the rate of entry of foreign workers. Prevention and control of course have different meanings. Prevention means the process, method, or act of preventing, preventing, or rejecting, while control means the process, method, or act of controlling or curbing. Strict regulations are one of the efforts to control foreign workers.

Law No. 13 of 2003 concerning Manpower (Manpower Law) in several articles has strictly regulated foreign workers starting from licensing, limiting positions and working period, plans for the use of foreign workers, competency standards, transfer of technology and expertise, assistant staff, job bans, compensation, and repatriation. . It's just that several rules in this law have been updated through Law no. 11 of 2020 concerning Omnibus Law.

Based on Law No. 13 of 2003 concerning Manpower, Article 43 paragraph (2), the Plan for the Use of Foreign Workers (RPTKA), at least contains information on a) the reasons for the use of foreign workers; $b$ ) the position and/or position of foreign workers in the organizational structure of the company concerned; c) the period of use of foreign workers; and d) the appointment of Indonesian citizen workers as companions of foreign workers who are employed. The Plan for Employment of Foreign Workers (RPTKA) must be approved by the Minister or appointed official. In this case, the Ministry of Manpower of the Republic of Indonesia and its subordinate agencies. Since the promulgation of Law no. 11 of 2020 concerning the Omnibus Law, specifically Article 81 paragraph (4), the Plan for the Use of Foreign Workers (RPTKA) was abolished and reappeared in the implementing regulations of Law no. 11 of 2020 concerning Omnibus Law, which is in the form of Government Regulation of the Republic of Indonesia No. 34 of 2021 concerning the
Use of Foreign Workers. Here it can be seen that the Government of Indonesia is inconsistent with its decisions. On the one hand, removing the Plan for Employment of Foreign Workers (RPTKA) which was approved by the Minister, on the other hand, bringing up the Plan for the Use of Foreign Workers (RPTKA). If this continues, then Indonesian Workers will lose their job opportunities so that jobs will also be lost. Therefore, Law no. 11 of 2020 does not take sides with Indonesian citizens to get a decent life and livelihood by the constitutional mandate of the 1945 Constitution of the Republic of Indonesia.

Based on Article 46 of the Manpower Law, Foreign Workers (TKA) are prohibited from occupying positions in charge of personnel and/or certain positions. Certain positions are regulated by a Ministerial Decree. Meanwhile, based on Law no. 11 of 2020 concerning the Omnibus Law, Article 42 paragraph (3), Exempted Foreign Workers are directors or commissioners with certain share ownership, diplomatic and consular employees, as well as Foreign Workers, needed due to emergencies, vocational training, startup companies, business visits, and studies. In-Law no. 11 of 2020, only prohibits Foreign Workers from serving in the personnel department, while the clause "and/or certain positions" is omitted. This means that Law No. 11 of 2020 provides exemptions for certain foreign workers from the obligation to have a foreign worker use plan (RPTKA). However, several other rules remain the same, such as the regulation regarding the prohibition of hiring foreign workers for individuals and several regulations regarding the employer's obligation to provide compensation, allow staff assistants, and require technology transfer, which is still regulated in Law no. 11 the Year 2020.

Some of the conveniences and simplifications regulated in the Omnibus Law certainly show that the rules for the use of foreign workers in the Omnibus Law provide more convenience for foreign workers to be able to work in Indonesia than the rules contained in the Manpower Act. It's just that with the Covid-19 Pandemic, the flow of traffic between countries should be greatly minimized to prevent the increasingly massive spread of Covid-19 including its new variants. The government through the relevant ministries issued several regulations aimed at restricting foreigners from entering Indonesian territory. The Ministry of Manpower of the Republic of Indonesia through a Circular Letter of the Minister of Manpower limits the use of foreign workers. This Circular is periodically updated by the development of Covid-19.

In February 2020, based on the Circular Letter of the Indonesian Ministry of Manpower No. M/I/HK.04/II/2020, the initial limitation was only on foreign workers who would be imported from China. Then the restriction rules apply to all foreign workers based on the Circular of the Ministry of Manpower No. 
M/4/HK.04/IV/2020. The latest restrictions apply to all foreign workers, except those working on National Strategic Projects (PSN) and strategic/national vital objects based on special written considerations/permissions from the relevant ministries/agencies based on the Circular Letter of the Indonesian Ministry of Manpower No. M/3/HK.04/II/2021.

\subsection{Weaknesses of Controlling Foreign Workers (TKA) Regulation}

The regulation on controlling foreign workers in the Omnibus Law contains several weaknesses related to the abolition of permits and minimum provisions that must be included in the Plan for the Use of Foreign Workers (RPTKA), the provision of exceptions to the obligation to ratify the Plan for the Use of Foreign Workers (RPTKA), and concessions to the ban on positions. Concerning licensing, the Manpower Law which strictly regulates the licensing process for foreign workers starting with a plan in advance, then issuing a permit has more restraining/controlling power when compared to the provisions in the Omnibus Law which only requires an endorsement. Ratification means the act of legitimizing, while one of the meanings of "authorizing" is "approving".

According to Bagir Manan, licensing in a broad sense is an agreement.[11] It's just that licensing is not only related to the aspect of approval, narrowly licensing also means binding to a regulation. This means that licensing does not only concern the imposition in special circumstances, but so that the permitted actions are carried out in a certain way/inscribed in the provisions.[12] Therefore, a permit must be accompanied by supervision. By changing the rules for licensing foreign workers to only ratification, of course, supervision efforts can be neglected.

Supervision of foreign workers is very important. At the time the licensing provisions in the Manpower Act were still in effect, there were many violations committed by foreign workers and employers of foreign workers, such as: working in Indonesia only on a tourist visa; work as manual labor that local workers should be able to do; work without any transfer of technology; and work beyond the specified period. To overcome this violation, of course, need supervision efforts, especially Labor Inspection. It's just that the Omnibus Law does not change the rules of Labor Inspection in the Manpower Act. The supervision rules in the Omnibus Law need to be tightened to compensate for the leeway that the law provides for foreign workers.

Omnibus Law also removes detailed provisions regarding what minimum things must be in a Plan for the Use of Foreign Workers (RPTKA). The minimum provisions are withdrawn as the contents of the
Government Regulation of the Republic of Indonesia. Preferably, the abolition is not carried out to provide signs as restrictions on the government in carrying out the law. If it is not regulated, then the government can at any time give more lax rules to foreign workers.

Ironically, after the licensing provisions were abolished and approval for the use of foreign workers could be made through the Foreign Worker Employment Plan (RPTKA), the Omnibus Law also relaxed the provisions on exceptions to the approval of the Foreign Worker Employment Plan (RPTKA). Directors and commissioners can be granted exceptions, then if the employer considers that foreign workers are urgently needed, then there is no need to submit a Plan for the Use of Foreign Workers (RPTKA).

Control over foreign workers through the field of work that is prohibited for foreign workers is also narrowed, namely only for work in the personnel field. So that finally all job positions can be carried out by foreign workers, including work as manual labor, such as (Cleaning Service). Therefore, the Omnibus Law not only ignores licensing rules, but legalizes things that were previously prohibited in the Manpower Act to be carried out by foreign workers.

Constitutional Court Verdict No. 91/PUUXVIII/2020 (formal test cluster) and the Constitutional Court Verdict No. 6/PUU-XIX/2021 (material test cluster) has declared the Job Creation Act conditionally unconstitutional. The Constitutional Court Verdict ordered the repairs for 2 years to be repaired (and also explained in the judicial review decision). So the 2 year period is to improve the law, not to implement it. This is proven by not being allowed to issue implementing regulations based on the Omnibus Law. Within 2 years, if the legislators, namely the Government and the House of Representatives (DPR) are unable to complete the Omnibus Law, then the law or articles or material content of the law that has been revoked or amended by the Omnibus Law must be declared valid again. The Constitutional Court Verdict stated that the Employment Creation Law was still in effect until an amendment was made to its formation by the grace period. People who are blind to the law, are confused by the statement of enforcement. This shows the indecisiveness of the panel of judges in making decisions.

Chapter IV of the Omnibus Law, referred to and known as the labor cluster, is considered to be very detrimental to the constitutional rights of workers/laborers and trade unions/labor unions as regulated in the 1945 Constitution of the Republic of Indonesia. The Petitioners disputed the constitutionality of the rules for interim work agreements as regulated in Article 81 number 15, number 19, number 25, number 29 , number 44 of the Omnibus Law. 
In addition, a formal and material review of the Omnibus Law was also proposed against Article 81 point 1 (Article 13 paragraph (1) letter c of Law No. 13 of 2003 concerning Manpower) regarding job training organized by the company's job training institution. In addition, Article 81 point 2 (Article 14 paragraph (1) of the Manpower Law) states that private job-training institutions as referred to in Article 13 paragraph (1) letter b of the Manpower Law are required to fulfill the Business Licensing issued by the Regency/Municipal Government.

During the pandemic, the influx of foreign workers remains unstoppable. The circular letter of the Ministry of Manpower of the Republic of Indonesia, was not heeded. For example, on March 15, 2020, 49 foreign workers from China continued to enter and work in Morosi, South Konawe.[13] In fact, at that time based on the Circular Letter of the Ministry of Manpower of the Republic of Indonesia No. M/I/HK.04/II/2020, foreign workers from China are prohibited from entering. Circular Letter of the Ministry of Manpower of the Republic of Indonesia No. M/4/HK.04/IV/2020 and the Republic of Indonesia Ministry of Manpower Circular No. M/3/HK.04/II/2021 also provides a gap for the entry of foreign workers through the exception rules for foreign workers who work on National Strategic Projects (PSN) and strategic/national vital objects. In addition, the Ministry of Manpower of the Republic of Indonesia through the Circular Letter of the Ministry of Manpower of the Republic of Indonesia No. M/3/HK.04/II/2021 has also given leeway to the relevant ministries/agencies to give special consideration/permission to the required foreign workers.

Actually, in 2015, the MEA Era, according to research by Agusmidah, et.al., Indonesia has protected the domestic job market and prevented the entry of skilled Foreign Workers (TKA) by implementing a negative list that is not by the free market climate in the ASEAN Economic Community (AEC). ) which will be implemented in ASEAN countries in the second half of 2015. However, restrictions on the entry of skilled foreign workers are still carried out by Indonesian government institutions, such as the Ministry of Health for doctors, dentists, and nurses, the Ministry of Public Works for surveying, and the Ministry of Tourism for the field of tourism professional work. Considering that strict regulations are not by the liberalization climate for skilled foreign workers within the MEA framework. Through literature study and analysis of legislation, this study finds that the restrictions on professional associations with certain competency standards aim to prevent the domestic job market from being dominated by skilled foreign workers in the 2015 MEA era. [14]

The House of Representatives of the Republic of Indonesia as the institution that supervises the Government must further enhance its monitoring efforts on the influx of foreign workers considering the lack of supervision efforts against foreign workers based on the Employment Creation Law and the increasing number of gaps for foreign workers to work in Indonesia. This supervision must, of course, take into account the need for the expertise of foreign workers, the availability of local workers, and the situation during the Covid-19 pandemic.

The public must also supervise various implementing regulations that emerged after the enactment of the Omnibus Law, including regulations issued by the relevant ministries. The government must be responsible for strengthening the rules of labor inspection that have not been corrected in the Omnibus Law. Strengthening the rules needs to be done immediately and not only during the pandemic, but forever.

\section{CONCLUSION}

Omnibus Law has changed the concept of controlling foreign workers which was previously strictly regulated in the Manpower Act. Various concessions were made, starting from replacing permits with ratification; the existence of exclusion provisions; and slack of office. This loosening of regulations has an impact on the difficulty of monitoring efforts and making it easier for foreign workers to work in Indonesia, even during the Covid-19 Pandemic. The pandemic situation has increased the need for jobs and foreign investment. Therefore, the government needs to prioritize the use of local workers in foreign investment projects.

The loosening of regulations for controlling foreign workers in the Omnibus Law must be balanced with efforts to tighten supervision. Therefore, the House of Representatives of the Republic of Indonesia through its supervisory function needs to monitor the performance of the Government in controlling foreign workers. The government also needs to immediately improve the rules of Labor Inspection, either through revisions to the Omnibus Law Law or by submitting a Labor Inspection Bill. The Constitutional Court Verdict No. 91/PUUXVIII/2020 (formal test cluster) and the Constitutional Court Verdict No. 6/PUU-XIX/2021 (material test cluster) stated that the Omnibus Law was still in effect until an amendment was made to its formation by the grace period. Within 2 years, if the legislators, namely the Government and the People's Representative Council (DPR) cannot complete the Omnibus Law, then the law or articles or material content of the law that has been revoked or amended by the Omnibus Law must be declared valid again. 


\section{REFERENCES}

[1] CNNIndonesia.com., "PAN Minta Pemerintah Terbuka Soal Kedatangan TKA China", https://www.cnnindonesia.com/nasional/20210517 135257-32-643287/pan-minta-pemerintah-terbukasoal-kedatangan-tka-china., diakses Jumat, 01 Oktober 2021.

[2] BBCNews.com., "TKA China datang ke Indonesia di tengah larangan mudik, Semua hal terkait Tiongkok selalu menjadi isu politik", https://www.bbc.com/indonesia/indonesia57067431., diakses Jumat, 01 Oktober 2021.

[3] Harian Kompas, "Kedatangan 500 TKA China ke Sultra Ditunda, Ribuan Pekerja Lokal Terancam PHK”, diterbitkan Senin, 11 Mei 2020.

[4] Harian Kompas, "Kedatangan 500 TKA China ke Sultra Ditunda, Ribuan Pekerja Lokal Terancam PHK”, diterbitkan Senin, 11 Mei 2020.

[5] Berita Online ekonomi.bisnis.com, "500 TKA China Masuk Indonesia, Menaker Angkat Suara", diupload 25 Juni 2020, https://ekonomi.bisnis.com/read/20200625/12/125 7720/500-tka-china-masuk-indonesia-menakerangkat-suara., diakses Senin, 04 Oktober 2021.

[6] Harian Kompas, "TKA China Masuk Indonesia Saat Pandemi Covid-19, KSPI: Ironi, Pemerintah Harusnya Berpihak Buruh Nasional", diterbitkan Selasa, 11 Mei 2021.

[7] Nasution, B.J., (2014), "Kajian Filosofis tentang Konsep Keadilan dari Pemikiran Klasik sampai Pemikiran Modern", Yustisia Vol. 3 (2), MeiAgustus, hlm. 118-130.
[8] Appeldoorn, Van., dalam Ibrahim, J., 2007, Teori dan Metodologi Penelitian Hukum Normatif, Bayu Media Publishing, Malang, hlm. 8.

[9] Rajagukguk, E., 2001, "Globalisasi Hukum dan Kemajuan Teknologi: Implikasinya Bagi Pendidikan Hukum dan Pembangunan Hukum Indonesia," Pidato pada Dies Natalis Universitas Sumatera Utara Ke-44, di Kota Medan 20 Nopember 2001, hlm. 4.

[10] Friedman, L.M., 1990, Legal Culture and the Welfare State: Law and Society: An Introduction, Harvard University Press, Cambridge, Massachusetts, London, hlm. 89.

[11] Manan, B., 1995, "Ketentuan-ketentuan Mengenai Pengaturan Penyelenggaraan Hak Kemerdekaan Berkumpul Ditinjau Dari Perspektif UUD", Makalah, Jakarta, hlm. 8. Lihat juga: Sutedi, Adrian., 2010, Hukum Perizinan Dalam Sektor Pelayanan Publik, Sinar Grafika, Jakarta, hlm. 170.

[12] Ridwan, 2003, Hukum Administrasi Negara, UII Press, Yogyakarta, hlm. 151-152.

[13] Majalah Tempo, "49 WNA Asal Cina di Kendari, Tagar\#CopotKapoldaSultra Trending", diterbitkan Selasa, 17 Maret 2020.

[14] Agusmidah, et.al., (2016), "The Readiness of Foreign Workers Regulations in the Engineering and Medical Practitioners Sector Entering The Asean Economic Community", Jurnal Dinamika Hukum Vol. 16, (1), January, hlm. 31-38. 